\title{
ADSORPSI ION EMAS MENGGUNAKAN ASAM HUMAT TANAH GAMBUT DI BAWAH RADIASI SINAR UV
}

\author{
${ }^{1}$ P. Lestari \\ ${ }^{1}$ Jurusan Teknik Lingkungan, Fakultas Teknik Sipil dan Perencanaan \\ Universitas Islam Indonesia \\ Yogyakarta, Indonesia
}

e-mail: puji.lestari@uii.ac.id

\begin{abstract}
Abstrak
Berbagai upaya dapat dilakukan untuk mendulang kembali (recovery) emas dari limbah elektronik, salah satunya adalah melalui proses adsorpsi. Salah satu adsorben yang dapat digunakan untuk proses adsorpsi ion emas di dalam larutan adalah asam humat $(\mathrm{AH})$ hasil isolasi dari tanah gambut. Proses adsorpsi ion emas menggunakan $\mathrm{AH}$ tanah gambut diikuti dengan proses reduksi ion emas menjadi logam emas. Proses adsorpsi reduktif ini dapat ditingkatkan dengan penyinaran menggunakan sinar UV. Penelitian ini bertujuan untuk mempelajari proses adsorpsi ion emas menggunakan asam humat tanah gambut dengan adanya radiasi sinar UV. Proses adsorpsi ion emas dilakukan dengan metode batch dan parameter yang dipelajari antara lain $\mathrm{pH}$, waktu interaksi, serta variasi konsentrasi ion emas dalam larutan. $\mathrm{pH}$ optimum proses adsorpsi adalah 2. Proses adsorpsi ion emas pada $\mathrm{AH}$ tanah gambut di bawah radiasi UV mengikuti model kinetika adsorpsi yang diajukan oleh Santosa (2007) serta mengikuti model isotermal adsorpsi Langmuir. Radiasi sinar UV dapat membuat proses adsorpsi reduktif ion emas menggunakan $\mathrm{AH}$ tanah gambut menjadi lebih efektif. Kapasitas adsorpsi ion emas pada AH tanah gambut adalah 90,91 mg/g. Penambahan 2-propanol akan menurunkan efektivitas proses adsorpsi ion emas pada $\mathrm{AH}$ tanah gambut.
\end{abstract}

Kata kunci: Adsorpsi reduktif, asam humat, ion $\mathrm{Au}(\mathrm{III})$, sinar UV

\begin{abstract}
Many efforts are carried out in order to find effective methods to recover gold from the electronic scraps. One of the most applied and promising methods is adsorption process. One of the promising adsorbent for the adsorption of gold ions is humic acid. Humic acid can be found in an abundant amount in the nature. One source of humic acid that is abundantly available in Indonesia is peat soil. The adsorption process of gold ion onto peat soil humic acid is followed by the reduction of gold ion to its metal form. The reductive adsorption process can be enhanced by conducting the process under the UV light irradiation. This work aimed at investigating the reductive adsorption process of gold ion onto peat soil humic acid under the presence of UV light irradiation. The adsorption process was studied using batch method. The parameters studied in this work were $\mathrm{pH}$, interaction time and the initial concentration of gold ion. The optimum $\mathrm{pH}$ for the adsorption process is 2 . The adsorption process of gold ion onto peat soil humic acid under the UV light irradiation follows the kinetics model proposed by Santosa (2007) and fits the Langmuir isothermal model. The UV light irradiation can enhance the reductive adsorption process of gold ion onto peat soil humic acid. The adsorption capacity of peat soil humic acid for gold ion is $90.91 \mathrm{mg} / \mathrm{g}$. The addition of 2-propanol can decrease the effectiveness of reductive adsorption of gold ion onto peat soil humic acid.
\end{abstract}

Keywords: gold ion, humic acid, reductive adsorption, UV light irradiation 


\section{PENDAHULUAN}

Emas merupakan logam mulia yang diaplikasikan secara luas pada berbagai bidang. Dalam bidang elektronik, emas digunakan sebagai bahan pelapis komponen elektronik karena sifatnya yang tahan korosi serta konduktivitasnya yang hampir $100 \%$. Selama ini, emas dapat diperoleh dari bijihnya yang terdapat di alam dengan jumlah yang relatif sedikit yakni dalam 1 ton bijih emas, hanya terkandung sekitar 5-30 gram logam emas (Ogata \& Nakano, 2005). Mengingat tingginya kebutuhan logam emas, berbagai upaya dilakukan untuk mencari sumber emas baru selain dari hasil mendulang bijih emas di alam. Salah satu sumber emas yang menjanjikan adalah dari limbah peralatan elektronik. Jika dibandingkan dengan konsentrasi emas dalam bijihnya, konsentrasi emas dalam limbah elektronik relatif lebih tinggi yakni 200 gram dalam tiap ton limbah elektronik.

Proses pengambilan kembali (recovery) emas dari limbah elektronik sering kali dilakukan menggunakan material berbahaya, seperti pencucian menggunakan garam sianida atau asam nitrat serta proses amalgamasi menggunakan merkuri $(\mathrm{Hg})$ (Torre, et al., 2006; Rochat, et al., 2007). Di samping membutuhkan biaya yang relatif tinggi (untuk pengelolaan limbah sekunder yag dihasilkan dari proses recovery), proses ini tentu saja akan membahayakan. Di dalam air asam, merkuri dapat terkonversi menjadi metil merkuri dan dapat membahayakan janin serta dapat menyebabkan kerusakan pada otak. Oleh karena itu, berbagai upaya dilakukan untuk mencari senyawa di alam yang lebih ramah lingkungan untuk proses recovery emas dari limbah elektronik.
Karakteristik senyawa di alam yang dapat dimanfaatkan dalam proses recovery emas adalah tingginya kandungan gugus $\mathrm{OH}$ fenolat. Dalam proses recovery tersebut, ion emas tidak hanya diserap tetapi juga direduksi menjadi bentuk logamnya. Nakajima, et al. (2003) dan Parajuli et al. (2006) telah berhasil mengadsorpsi dan mereduksi ion emas menggunakan senyawa tannin yang terkandung dalam buah persik dan gel yang dibuat menggunakan kulit buah persik. Tannin merupakan suatu makromolekul yang kaya akan gugus $-\mathrm{OH}$ fenolat.

Salah satu senyawa alami yang dilaporkan dapat digunakan sebagai adsorben logam emas adalah asam humat $(\mathrm{AH})$. Struktur hipotetik $\mathrm{AH}$ diberikan pada Gambar 1.

$\mathrm{AH}$ merupakan senyawa makromolekul yang kaya akan gugus $\mathrm{COOH},-\mathrm{OH}$ fenolat maupun $-\mathrm{OH}$ alkohol (Stevenson, 1994). Gugus-gugus fungsi inilah yang sangat berperan dalam proses adsorpsi reduktif ion emas dalam larutan. Gugus-gugus fungsi pada $\mathrm{AH}$ dapat membentuk kompleks dengan kation logam, terutama logam transisi. Selain itu, gugus $-\mathrm{OH}$ fenolat pada $\mathrm{AH}$ dapat mereduksi kation logam. Lestari (2017) melaporkan bahwa $\mathrm{AH}$ hasil isolasi tanah gambut Kalimantan Selatan dapat digunakan untuk mengadsorpsi ion emas dalam larutan dan mereduksinya menjadi logam emas. Adanya logam emas yang terbentuk dikonfirmasi dengan adanya puncak serapan logam emas $(\mathrm{Au}(0))$ pada difraktogram XRD $\mathrm{AH}$ setelah proses adsorpsi berlangsung. Kapasitas adsorpsi ion emas pada $\mathrm{AH}$ tanah gambut adalah $90,91 \mathrm{mg} / \mathrm{g}$ (Lestari, 2017). 


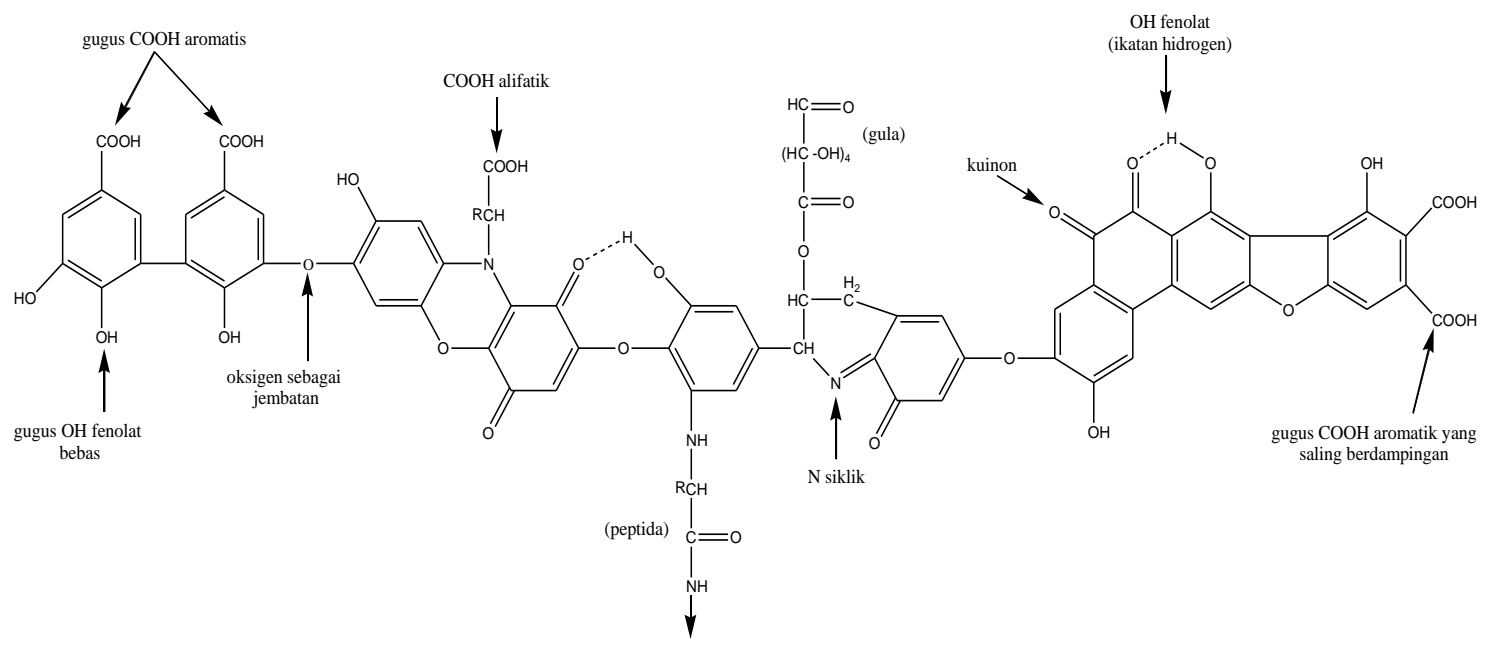

Gambar 1. Struktur hipotetik asam humat (Stevenson, 1994)

Studi menunjukkan bahwa $\mathrm{AH}$ dapat berperan sebagai photo sensitizer melalui pembentukan senyawa antara (intermediate) reaktif seperti spesies oksigen reaktif (ROS), atau melalui pembentukan radikal bebas yang relatif stabil (Polewski, et al., 2005). Apabila AH di dalam air menyerap energi solar (ultraviolet), $\mathrm{AH}$ dapat bertindak sebagai sensitizer dalam pembentukan senyawa intermediat reaktif seperti radikal hidroksil, elektron terlarut, anion superoksida, hidrogen peroksida dan lainnya (Stumm \& Morgan, 1996). Senyawa-senyawa intermediat reaktif tersebut dapat berperan dalam proses reduksi ion logam. Oleh karena itu, pada penelitian ini, akan dipelajari pengaruh radiasi sinar ultraviolet (UV) pada proses adsorpsi reduktif ion emas menggunakan $\mathrm{AH}$ hasil isolasi tanah gambut. Dengan adanya radiasi UV, proses adsorpsi reduktif ion emas menggunakan $\mathrm{AH}$ tanah gambut diharapkan dapat berlangsung dengan lebih efektif baik dari segi waktu maupun jumlah ion yang terserap.

\section{METODE}

\section{Bahan}

$\mathrm{AH}$ diisolasi dari tanah gambut Kalimantan Selatan menggunakan metode ekstraksi basa. Bahan-bahan kimia yang digunakan pada penelitian ini adalah produksi E. Merck tanpa pemurnian lebih lanjut: $\mathrm{NaOH}, \mathrm{HCl}, \mathrm{HF}, \mathrm{AgNO}_{3}, \mathrm{Ba}(\mathrm{OH})_{2}$, $\mathrm{Ca}\left(\mathrm{CH}_{3} \mathrm{COO}\right)_{2} \cdot \mathrm{H}_{2} \mathrm{O}$, CuCl. $2 \mathrm{H}_{2} \mathrm{O}$, larutan standar $\mathrm{AuCl}_{4}^{-} 1000$ ppm.

\section{Eksperimen}

Penelitian dilakukan di laboratorium dengan menginteraksikan $\mathrm{AH}$ tanah gambut dengan ion emas (larutan $\mathrm{AuCl}_{4}{ }^{-}$) pada berbagai variasi $\mathrm{pH}$, waktu interaksi dan variasi konsentrasi awal ion emas di bawah radiasi sinar UV. Ion $\mathrm{AuCl}_{4}^{-}$yang tersisa setelah proses adsorpsi reduktif diukur menggunakan spektrofotometer UV-Vis. Untuk mempelajari pengaruh radiasi sinar UV pada proses pembentukan radikal $\mathrm{OH}, \mathrm{AH}$ dan ion emas diinteraksikan dengan 2-propanol pada berbagai konsentrasi. 2-propanol dapat bertindak sebagai penangkap (scavenger) radikal $\mathrm{OH}$ yang terbentuk.

Pada penelitian ini, $\mathrm{AH}$ diisolasi dari tanah gambut dengan metode ekstraksi menggunakan larutan alkali $(\mathrm{NaOH})$ encer di bawah atmosfer nitrogen karena penggunaan larutan alkali pada proses ekstraksi $\mathrm{AH}$ dapat menyebabkan auto oksidasi molekul $\mathrm{AH}$. $\mathrm{NaOH}$ merupakan bahan pengekstrak yang paling efektif untuk memisahkan $\mathrm{AH}$ dari tanah secara kuantitatif.

\section{Pengaruh $\mathrm{pH}$ awal larutan}

Suatu seri larutan $\mathrm{AuCl}_{4}^{-}$dengan konsentrasi 50 ppm sebanyak $10 \mathrm{ml}$ disiapkan dan diatur pH-nya menjadi 1, 2, 3 , dan 4 menggunakan larutan $\mathrm{NaOH}$ dan $\mathrm{HCl}$ encer. $\mathrm{AH}$ sebanyak $10 \mathrm{mg}$ kemudian ditambahkan ke dalam masing-masing larutan dan diinteraksikan selama 24 jam pada temperatur kamar di bawah radiasi lampu UV $(\lambda=254 \mathrm{~nm})$. Larutan kemudian disaring menggunakan kertas Whatman42. Ion $\mathrm{AuCl}_{4}^{-}$yang tersisa diukur menggunakan spektrofotometer UV-Vis 
(Shimadzu UV-1700 PharmaSpec) pada panjang gelombang maksimum $\mathrm{AuCl}_{4}{ }^{-}$, yakni 314 nm (Paclawski \& Sak, 2015).

\section{Pengaruh waktu interaksi}

Suatu seri larutan $\mathrm{AuCl}_{4}^{-}$ konsentrasi 50 ppm sebanyak $10 \mathrm{~mL}$ disiapkan dan diatur $\mathrm{pH}$ menjadi 2 menggunakan larutan $\mathrm{NaOH}$ dan $\mathrm{HCl}$ encer. Sebanyak $10 \mathrm{mg} \mathrm{AH}$ ditambahkan ke dalam masing-masing larutan dan diinteraksikan selama 24 jam pada temperatur kamar di bawah radiasi lampu UV $(\lambda=254 \mathrm{~nm})$. Larutan kemudian segera disaring menggunakan kertas Whatman-42 pada setiap waktu interaksi yang telah ditentukan. Ion $\mathrm{AuCl}_{4}^{-}$yang tersisa diukur menggunakan spektrofotometer UV-Vis.

Waktu interaksi yang digunakan adalah $60,120,180,240,300,360,420$, $540,600,900,1200$, dan 1440 menit. Data percobaan yang diperoleh kemudian dianalisis untuk menentukan konstanta laju dari proses adsorpsi reduktif. Model kinetika yang digunakan pada penelitian ini adalah model kinetika LangmuirHinselwood dan model kinetika Santosa (2007).

Persamaan kinetika LangmuirHinselwood disajikan pada persamaan 1.

$$
\frac{\ln \left(\frac{C_{O}}{C_{A}}\right)}{C_{O}-C_{A}}+K=\frac{k_{1} t}{C_{O}-C_{A}}
$$

$\mathrm{C}_{0}$ adalah konsentrasi awal, $\mathrm{C}_{\mathrm{A}}$ adalah konsentrasi saat waktu $t, t$ adalah waktu adsorpsi, $\mathrm{K}$ adalah konstanta kesetimbangan adsorpsi dan $\mathrm{k}_{1}$ adalah konstanta laju adsorpsi.

Persamaan model kinetika Santosa (2007) dís@jjkàn pada persamaan 2.

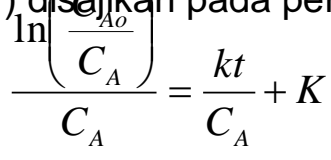

$\mathrm{C}_{\mathrm{Ao}}$ adalah konsentrasi awal, $\mathrm{C}_{\mathrm{A}}$ adalah konsentrasi saat waktu $t$, $t$ adalah waktu adsorpsi, $\mathrm{K}$ adalah konstanta kesetimbangan adsorpsi dan $\mathrm{k}_{1}$ adalah konstanta laju adsorpsi.

(2)

Pengaruh konsentrasi awal $\mathrm{AuCl}_{4}$

$\mathrm{AH}$ sebanyak $10 \mathrm{mg}$ diinteraksikan dengan larutan $\mathrm{AuCl}_{4}^{-}$berbagai konsentrasi: 30, 50, 150, 200, dan 250 ppm pada $\mathrm{pH} 2$ selama 24 jam di bawah radiasi lampu UV $(\lambda=254 \mathrm{~nm})$. Setelah proses interaksi, larutan kemudian disaring menggunakan kertas Whatman-42 dan $\mathrm{AuCl}_{4}^{-}$yang tersisa setelah proses adsorpsi diukur menggunakan spektrofotometer UV-Vis pada panjang gelombang $314 \mathrm{~nm}$. Data percobaan kemudian dianalisis menggunakan model isotermal adsorpsi Langmuir dan Freundlich.

Model isotermal adsorpsi Langmuir diberikan pada persamaan 3.

$$
\frac{C_{a}}{q}=\frac{C_{a}}{q_{\max }}+\frac{1}{q_{\max } K_{L}}
$$

$\mathrm{C}_{\mathrm{a}}$ adalah konsentrasi adsorbat yang tersisa dalam larutan, $q$ adalah konsentrasi adsorbat yang teradsorpsi pada adsorben pada kesetimbangan, $q_{\max }$ adalah kapasitas adsorpsi maksimum adsorben, dan $\mathrm{K}_{\mathrm{L}}$ adalah konstanta Langmuir.

Model isotermal adsorpsi Langmuir diberikan pada persamaan 4 .

$$
\log q=\log K_{F}+\frac{1}{n} \log C a
$$

$\mathrm{K}_{\mathrm{F}}$ adalah konstanta Freundlich dan $\mathrm{n}$ adalah konstanta.

\section{Pengaruh penambahan 2-propanol}

Larutan $\mathrm{AuCl}_{4}^{-}$sebanyak $10 \mathrm{~mL}$ diinteraksikan dengan $10 \mathrm{mg} \mathrm{AH}$. Larutan 2-propanol dengan berbagai konsentrasi kemudian ditambahkan ke dalam campuran tersebut dan diinteraksikan selama 24 jam di bawah radiasi lampu UV $(\lambda=254 \mathrm{~nm})$. Campuran selanjutnya disaring menggunakan Whatman 42 dan dianalisis menggunakan instrumen spektrofotometer UV-Vis untuk mengukur konsentrasi $\mathrm{AuCl}_{4}^{-}$yang tersisa di dalam larutan.

\section{HASIL DAN PEMBAHASAN \\ Pengaruh pH awal larutan}

$\mathrm{pH}$ larutan merupakan parameter yang sangat penting dalam proses adsorpsi karena perubahan $\mathrm{pH}$ larutan dapat menyebabkan perubahan bentuk spesies logam di dalam larutan. Pada percobaan pengaruh $\mathrm{pH}$ awal larutan pada proses adsorpsi reduktif ion emas $\left(\mathrm{AuCl}_{4}^{-}\right)$ menggunakan $\mathrm{AH}$ tanah gambut, $\mathrm{pH}$ yang digunakan adalah suasana asam $(\mathrm{pH} 1-4)$ 
karena $\mathrm{AH}$ merupakan fraksi senyawa humat yang larut pada kondisi basa, sehingga akan sulit dipisahkan dari larutan setelah proses adsorpsi. Pengaruh $\mathrm{pH}$ awal larutan pada proses adsorpsi reduktif $\mathrm{AuCl}_{4}^{-}$menggunakan $\mathrm{AH}$ tanah gambut diberikan pada Tabel 1. Dari Tabel 1, terlihat bahwa proses adsorpsi reduktif ion emas pada $\mathrm{AH}$ tanah gambut paling optimal terjadi pada $\mathrm{pH}$ 2. Pada $\mathrm{pH} 2$, gugus fungsi $-\mathrm{COOH}$ dan $-\mathrm{OH}$ fenolat pada $\mathrm{AH}$ akan mengalami protonasi sehingga menjadi bermuatan parsial positif. Hal ini akan menyebabkan interaksi elektrostatik antara $\mathrm{AH}$ dengan ion $\mathrm{AuCl}_{4}^{-}$ yang memiliki muatan negatif menjadi semakin efektif. Selain itu, pada $\mathrm{pH} 2$, spesies $\mathrm{Au}$ (III) masih dominan berada dalam bentuk $\mathrm{AuCl}_{4}^{-}$, seperti yang ditunjukkan oleh grafik distribusi spesies
$\mathrm{Au}$ (III) dalam berbagai kondisi $\mathrm{pH}$ pada Gambar 2.

Efektifitas proses adsorpsi reduktif $\mathrm{AuCl}_{4}^{-}$pada $\mathrm{AH}$ tanah gambut akan menurun pada $\mathrm{pH}$ di atas 2 akibat adanya reaksi hidrolisis $\mathrm{AuCl}_{4}^{-}$yang akan mengurangi jumlah spesies $\mathrm{AuCl}_{4}^{-}$yang ada di dalam larutan (Wang, et al., 2009). Selain itu, di atas $\mathrm{pH} 2$, gugus fungsi $\mathrm{COOH}$ pada $\mathrm{AH}$ akan terdeprotonasi membentuk -COO- sehingga akan pula mengurangi efektifitas interaksi antara ion $\mathrm{AuCl}_{4}^{-}$dan $\mathrm{AH}$. Di bawah pH 2, efektifitas proses adsorpsi $\mathrm{AuCl}_{4}^{-}$pada $\mathrm{AH}$ juga mengalami penurunan karena tingginya konsentrasi ion $\mathrm{Cl}^{-}$yang ada di dalam larutan. Ion $\mathrm{Cl}^{-}$akan menghambat proses adsorpsi yang terjadi melalui pembentukan kompleks $\mathrm{AuCl}_{4}^{-}$yang relatif stabil.

Tabel 1. Adsorpsi reduktif $\mathrm{AuCl}_{4}^{-}$menggunakan $\mathrm{AH}$ tanah gambut pada berbagai $\mathrm{pH}$

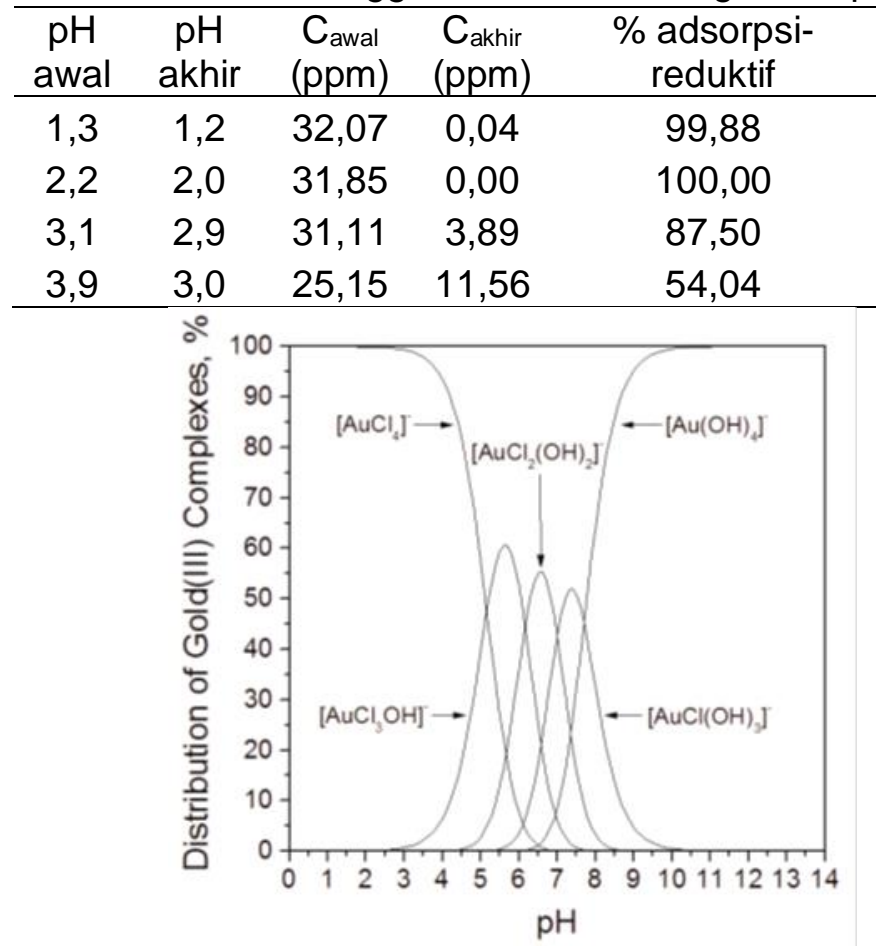

Gambar 2. Distribusi ion kompleks Au(III) pada berbagai pH (Paclawski \& Fitzner, 2004)

Dari Tabel 1, terlihat pula bahwa $\mathrm{pH}$ larutan mengalami penurunan setelah proses adsorpsi berlangsung. Hal ini disebabkan karena lepasnya ion-ion

$$
\mathrm{AuCl}_{4}^{-}+3 \mathrm{Ar}-\mathrm{OH} \rightarrow \mathrm{Au}^{0}+3 \mathrm{Ar}=\mathrm{O}+3 \mathrm{H}^{+}+4 \mathrm{Cl}^{-}
$$

Lestari (2017) melaporkan bahwa pada $\mathrm{pH} 2$, $\mathrm{AH}$ mampu mengadsorpsi hidrogen dari gugus $-\mathrm{OH}$ fenolat selama proses reduksi ion emas berlangsung, hal ini sesuai dengan reaksi pada persamaan 5.

$\mathrm{AuCl}_{4}^{-}$hingga $81,04 \%$. Pada percobaan ini, proses adsorpsi $\mathrm{AuCl}_{4}^{-}$pada $\mathrm{pH}$ yang sama 
mencapai $100 \%$. Hal ini menunjukkan bahwa adanya radiasi sinar UV akan mampu meningkatkan proses adsorpsi reduktif $\mathrm{AuCl}_{4}^{-}$pada $\mathrm{AH}$ tanah gambut. Apabila $\mathrm{AH}$ menyerap energi dengan $\lambda$ tertentu, $\mathrm{AH}$ akan dapat berperan sebagai sensitizer dalam pembentukan senyawa intermediat reaktif yang berperan dalam proses reduksi ion emas menjadi logam emas.

Interaksi $\mathrm{AH}$ dengan ion emas dapat<smiles>Cc1cc2c(cc1C)C(=O)ONO2</smiles>

(a) berlangsung melalui beberapa mekanisme, seperti pembentukan ikatan hidrogen, interaksi elektrostatik, ikatan koordinasi maupun pembentukan kelat (Stevenson, 1994). Sedangkan proses pengikatan ion logam emas dengan molekul $\mathrm{AH}$ dapat berlangsung melalui pembentukan kelat baik antara gugus karboksilat dengan gugus - $\mathrm{OH}$ fenolat maupun antara 2 gugus karboksilat, seperti yang ditunjukkan pada Gambar 3.<smiles>[M]OC(=O)c1cc(C)c(C)cc1C(=O)O</smiles>

Gambar 3. Pembentukan kelat antara ion logam emas (M) dengan (a): gugus karboksilat dan $-\mathrm{OH}$ fenolat; dan (b): dua gugus karboksilat (Manahan, 2000)

\section{Pengaruh waktu interaksi}

Percobaan pengaruh waktu interaksi digunakan untuk mempelajari model kinetika adsorpsi $\mathrm{AuCl}_{4}^{-}$pada $\mathrm{AH}$ tanah gambut di bawah radiasi UV. Model kinetika adsorpsi digunakan untuk menentukan konstanta laju reaksi proses adsorpsi. Grafik model kinetika adsorpsi Langmuir-Hinselwoods untuk adsorpsi $\mathrm{AuCl}_{4}^{-}$pada $\mathrm{AH}$ tanah gambut disajikan pada Gambar 4.

Nilai konstanta kesetimbangan, $\mathrm{K}$, dapat diperoleh dari nilai intersep grafik pada Gambar 4. Pada proses adsorpsi $\mathrm{AuCl}_{4}^{-}$menggunakan $\mathrm{AH}$ tanah gambut, model kinetika Langmuir-Hinselwoods memberikan harga $\mathrm{K}$ yang bernilai negatif. Secara termodinamika, hal ini tidak dapat diterima. Oleh karena itu, model kinetika adsorpsi yang diajukan oleh (Santosa, et al., 2007) digunakan pula untuk mempelajari model kinetika proses adsorpsi, disajikan pada Gambar 5.

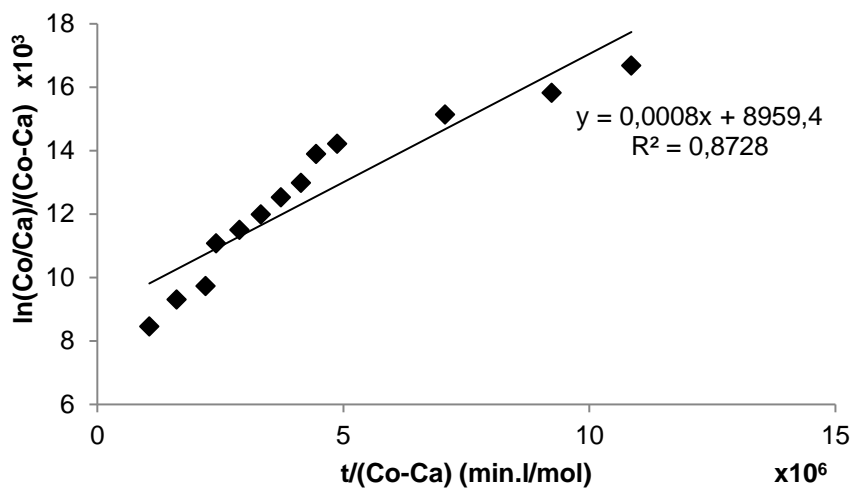

Gambar 4. Grafik model kinetika Langmuir-Hinselwoods untuk adsorpsi $\mathrm{AuCl}_{4}^{-}$pada $\mathrm{AH}$ tanah gambut 


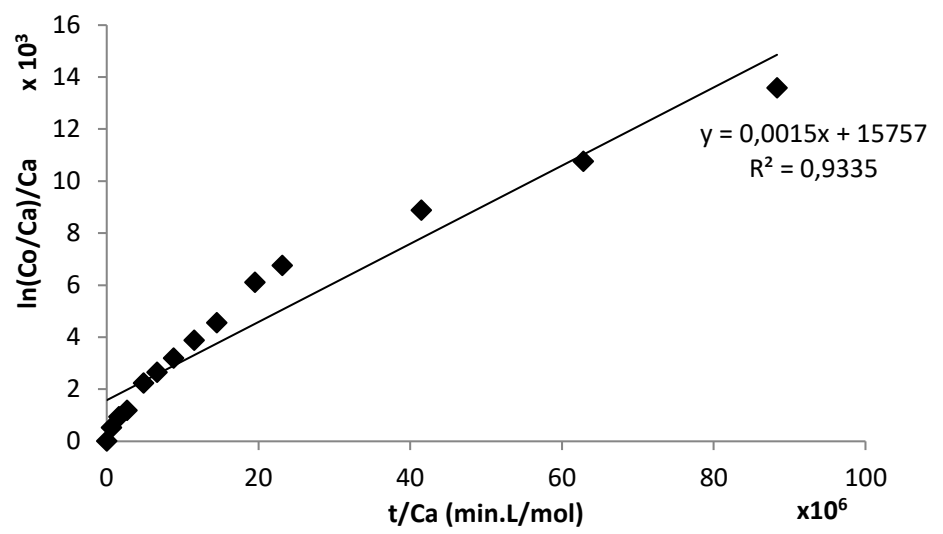

Gambar 5. Grafik model kinetika Santosa (2007) untuk adsorpsi $\mathrm{AuCl}_{4}^{-}$pada $\mathrm{AH}$ tanah gambut

Dari slope pada Gambar 5, diperoleh nilai konstanta laju adsorpsi sebesar 0,0015 menit $^{-1}$. Nilai ini lebih tinggi dibandingkan dengan konstanta laju adsorpsi ion emas menggunakan $\mathrm{AH}$ tanah gambut tanpa adanya sinar UV, yakni 0,0011 menit $^{-1}$ (Lestari, 2017). Selain itu, di bawah radiasi sinar UV nilai konstanta kesetimbangan, $\mathrm{K}$, juga mengalami peningkatan dari $6351,7 \mathrm{~L} / \mathrm{mol}$ menjadi $15757 \mathrm{~L} / \mathrm{mol}$, diperoleh dari nilai intersep grafik pada Gambar 5.
Pengaruh konsentrasi awal $\mathrm{AuCl}_{4}^{-}$

Pengaruh konsentrasi awal larutan $\mathrm{AuCl}_{4}^{-}$terhadap persentase adsorpsi reduktif $\mathrm{AuCl}_{4}^{-}$menggunakan $\mathrm{AH}$ tanah gambut disajikan pada Gambar 6. Gambar 6 menunjukkan bahwa semakin tinggi konsentrasi larutan $\mathrm{AuCl}_{4}^{-}$, persentase adsorpsi reduktif semakin menurun. Hal ini dikarenakan pada konsentrasi tinggi, situs aktif yang ada pada $\mathrm{AH}$ seluruhnya telah terisi oleh adsorbat sehingga menurunkan jumlah adsorbat yang dapat terikat pada adsorben $\mathrm{AH}$.

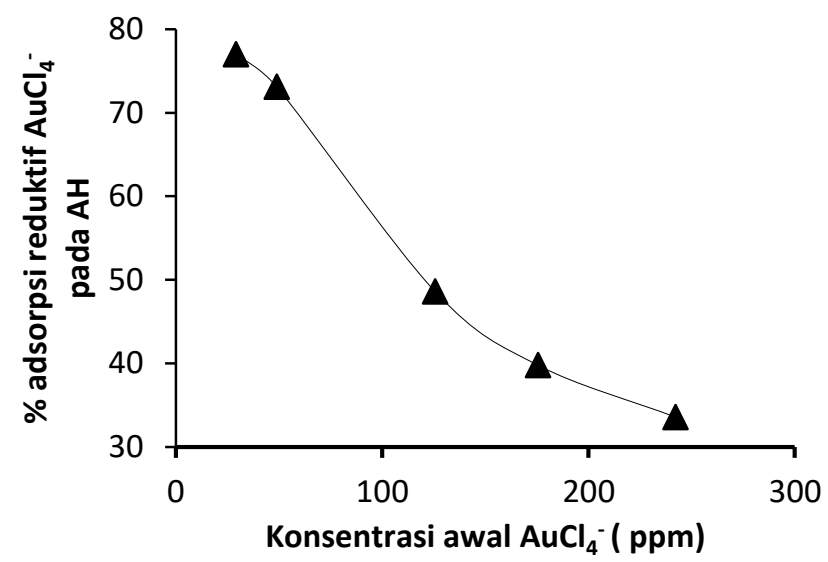

Gambar 6. Pengaruh konsentrasi awal $\mathrm{AuCl}_{4}^{-}$pada $\mathrm{AH}$ tanah gambut di bawah radiasi UV

Penentuan model isotermal adsorpsi $\mathrm{AuCl}_{4}^{-}$pada $\mathrm{AH}$ tanah gambut di bawah radiasi sinar UV dilakukan menggunakan model isotermal adsorpsi Langmuir dan Freundlich. Isotermal adsorpsi Langmuir ditentukan dengan membuat grafik antara $\mathrm{Ca} / \mathrm{q}$ versus $\mathrm{Ca}$ (Gambar 7), sedangkan isotermal adsorpsi Freundlich ditentukan dengan membuat grafik log q versus log $\mathrm{Ca}$ (Gambar 8). 


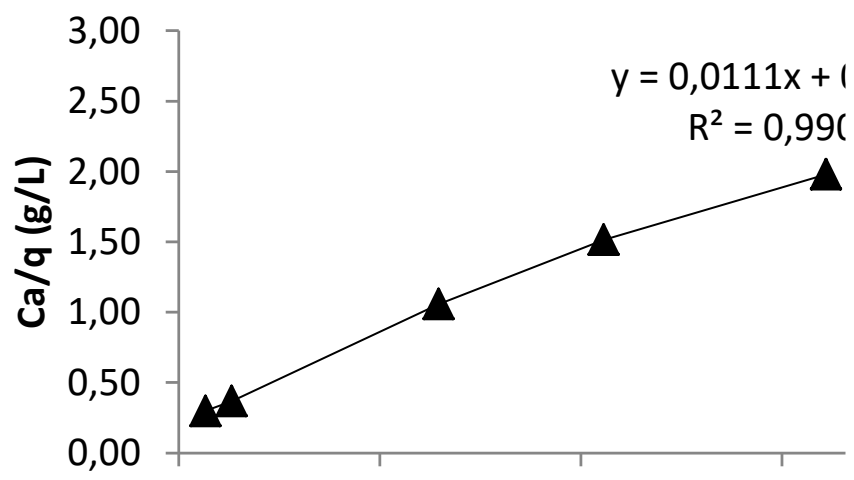

Gambar 7. Grafik $\mathrm{Ca}$ /q versus $\mathrm{Ca}$

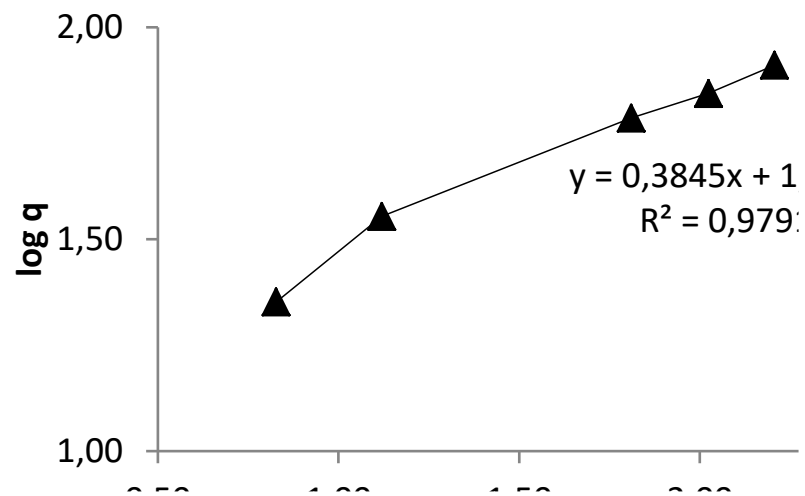

Gâmb̄ar 8. Grafîik log q verŝus log Ĉâ

Grafik model isotermal Langmuir memberikan kurva linier dengan nilai faktor korelasi $\left(R^{2}\right)$ sebesar 0,99. Dari nilai slope, kapasitas adsorpsi ion $\mathrm{AuCl}_{4}^{-}$pada asam humat tanah gambut dengan adanya radiasi UV dapat ditentukan, yakni 90,91 $\mathrm{mg} / \mathrm{g}$.

Grafik model isotermal adsorpsi Freundlich pada Gambar 8 juga memberikan kurva linier dengan nilai faktor korelasi $\left(R^{2}\right)$ sebesar 0,98. Dari perhitungan menggunakan slope dan intersep, diperoleh nilai $n$ sebesar 2,60 dan nilai $K_{F}$ sebesar $11,89 \mathrm{mg} / \mathrm{g}$.

\section{Pengaruh penambahan 2-propanol}

Eksperimen pengaruh penambahan 2-propanol pada proses adsorpsi reduktif $\mathrm{AuCl}_{4}^{-}$pada $\mathrm{AH}$ tanah gambut dilakukan untuk mempelajari peran gugus $-\mathrm{OH}$ fenolat $\mathrm{AH}$ pada proses adsorpsi reduktif. Reaksi reduksi $\mathrm{AuCl}_{4}^{-}$oleh $\mathrm{AH}$ sesuai dengan reaksi pada persamaan 5 .

Gugus $-\mathrm{OH}$ fenolat pada $\mathrm{AH}$ berperan pada proses adsorpsi reduktif melalui pembentukan radikal $\mathrm{OH}$. 2propanol akan bertindak sebagai penangkap (scavenger) radikal $\mathrm{OH}$ yang terbentuk selama proses adsorpsi reduktif $\mathrm{AuCl}_{4}{ }^{-}$. Hasil percobaan disajikan pada Gambar 9. 


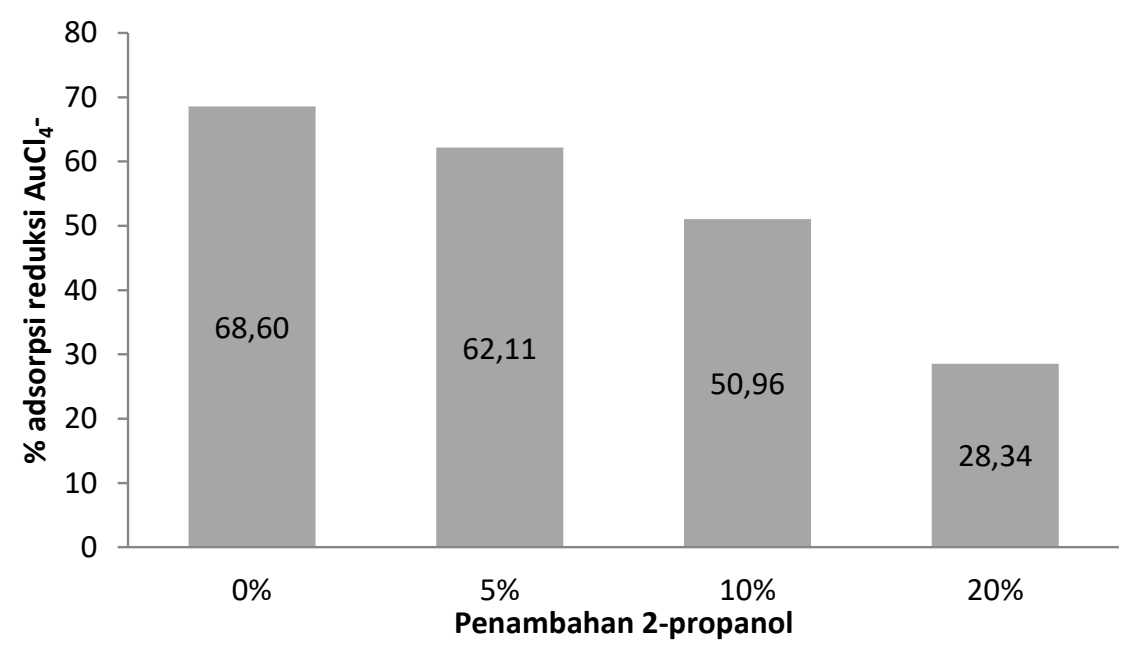

Gambar 9. Pengaruh penambahan 2-propanol

Semakin tinggi konsentrasi 2propanol yang ditambahkan, proses adsorpsi reduktif $\mathrm{AuCl}_{4}^{-}$menggunakan $\mathrm{AH}$ tanah gambut menjadi semakin tidak efektif. Hal ini dikarenakan 2-propanol memberikan pengaruh terhadap proses reduksi $\mathrm{AuCl}_{4}^{-}$menjadi $\mathrm{Au}(0)$. Tanpa penambahan 2-propanol, persentase adsorpsi reduktif mencapai $68,60 \%$. Persentase ini menurun menjadi $28,34 \%$ ketika 2-propanol dengan konsentrasi $20 \%$ ditambahkan ke dalam larutan.

2-propanol dapat bertindak sebagai penangkap (scavenger) radikal $\mathrm{OH}$ yang terbentuk selama proses reduksi. Mekanisme reaksi antara radikal $\mathrm{OH}$ dengan 2-propanol diberikan pada Gambar 10.

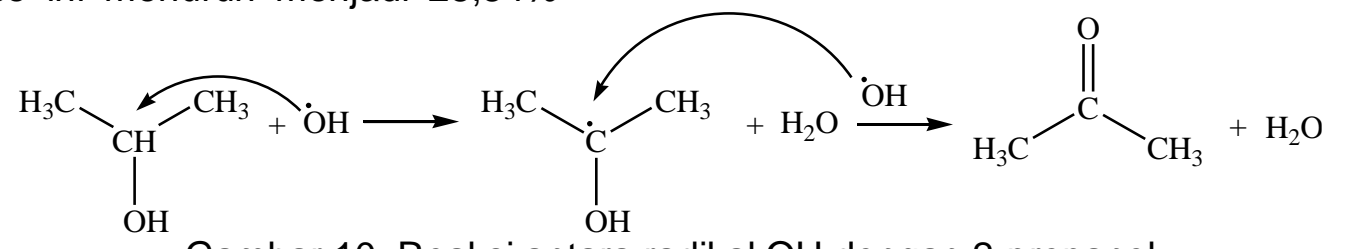

Gambar 10. Reaksi antara radikal $\mathrm{OH}$ dengan 2-propanol

\section{SIMPULAN}

Proses adsorpsi reduktif ion emas pada asam humat tanah gambut terjadi paling optimum pada $\mathrm{pH}$ 2. Tanpa adanya radiasi UV, persentase adsorpsi reduktif ion emas pada asam humat tanah gambut pada $\mathrm{pH} 2$ adalah $81,04 \%$. Dengan adanya radiasi sinar UV, persentase ini meningkat menjadi $100 \%$. Kapasitas adsorpsi ion emas pada asam humat tanah gambut di bawah radiasi UV adalah $90,91 \mathrm{mg} / \mathrm{g}$. Peningkatan proses adsorpsi reduktif ion emas pada asam humat tanah gambut juga terlihat dari meningkatnya nilai konstanta laju adsorpsi dari 0,0011 menit ${ }^{-1}$ menjadi 0,0015 menit $^{-1}$.

Penambahan 2-propanol dapat menurunkan efektivitas adorpsi reduktif ion emas pada asam humat tanah gambut. Tanpa penambahan 2-propanol, persentase proses adsorpsi reduktif mencapai $68,60 \%$. Persentase ini menurun menjadi $28,34 \%$ dengan adanya penambahan 2-propanol 20\%. 2-propanol dapat bertindak sebagai penangkap (scavenger) radikal $\mathrm{OH}$ yang terbentuk selama proses reduksi.

\section{SARAN}

Asam humat tanah gambut menunjukkan kemampuan adsorpsi yang tinggi terhadap ion emas. Penelitian lanjutan diperlukan untuk menemukan metode yang efektif untuk memisahkan logam emas yang terbentuk setelah proses adsorpsi berlangsung.

\section{DAFTAR PUSTAKA}

Lestari, P. (2017). Isolation of Humic Acid from Peat Soil and Its Application as an Adsorbent for AuCl4- in Solution. 
AIP Conference Proceedings 1823. Yogyakarta.

Manahan, S. (2000). Environmental Chemistry, 7th edition. Florida: Lewish Publishers.

Nakajima, A., Ohe, K., Baba, Y., \& Kijima, T. (2003). Mechanism of Gold Adsorption by Persimmon Tannin Gel. Analytical Sci., 1075-1077.

Ogata, T., \& Nakano, Y. (2005). Mechanisms of Gold Recovery from Aqueous Solutions Using a Novel Tannin Gel Adsorbent Synthesized from Natural Condensed Tannin. Water Resources, 4281-4286.

Paclawski, K., \& Fitzner, K. (2004). Kinetics of Gold(III) Chloride Complex Reduction Using Sulfur(IV). Metall. Mat.Trans. B., 35; 1071-1085.

Paclawski, K., \& Sak, T. (2015). Kinetics and Mechanism of the Reaction of Gold(III) Chloride Complexes with Formic Acid. J. Min. Metall. Sect. BMetall. 51, 133 - 142 . J. Min. Metall. Sect. B-Metall., $133-142$.

Parajuli, D., Adhikari, C., Kuriyama, M., Kawakita, H., Ohto, K., Inoue, K., et al. (2006). Selective Recovery of Gold by Novel Lignin-Based Adsorption Gel. Ind. Eng. Chem. Res., 8-14.

Polewski, K., Slawińska, D., Slawiński, J., \& Pawlak, A. (2005). The Effect Of UV and Visible Light Radiation On Natural Humic Acid EPR Spectra and Kinetic Studies. Geoderma, 291-299.

Rochat, D., Hageluken, C., Keller, M., \& Widmer, R. (2007). Optimal Recycling for Printed Wiring Boards (PWBs) in India. Proceeding of the R'07 World Congress Recovery of
Materials and Energy for Resources Efficiency. Davos, Switzerland.

Santosa, S., Siswanta, D., Kurniawan, A., \& Rahmanto, W. (2007). Hybrid of Chitin and Humic Acid as High Performance Sorbent for $\mathrm{Ni}(\mathrm{II})$. Surface Sci., 5155-5161.

Stevenson, F. (1994). Humus Chemistry: Genesis, Compositions, Reactions. New York: John Wiley \& Sons Inc. .

Stumm, W., \& Morgan, J. (1996). Aquatic Chemistry: Chemical Equilibria and Rates in Natural Waters. 3rd edition. New York: John Wiley \& Sons Inc.

Torre, M., Bachiller, D., Rendueles, M., Menendez, C., \& Diaz, M. (2006). Cyanide Recovery from Gold Extraction Process Waste Effluents by Ion Exchange I.Equilibrium and Kinetics. Solvent Extr. Ion Exch. , 99-117.

Wang, S., Qian, K., Bi, X., \& Huang, W. (2009). Influence of Speciation of Aqueous $\mathrm{HAuCl} 4$ on the Synthesis, Structure, and Property of $\mathrm{Au}$ Colloids . J. Phys. Chem. C. , 65056510. 